\title{
Modelle van interreligieuse toleransie in die onderwys van die een-en-twintigste eeu
}

\author{
Authors: \\ Charste C. Wolhuter ${ }^{1}$ \\ Ferdinand J. Potgieter ${ }^{1}$ \\ Johannes L. van der Walt ${ }^{1}$ \\ Affiliations: \\ ${ }^{1}$ Faculty of Education \\ Sciences, North-West \\ University, Potchefstroom \\ Campus, South Africa \\ Correspondence to: \\ Ferdinand Potgieter ${ }^{1}$

\section{Email:} \\ ferdinand.potgieter@nwu. \\ ac.za
}

Postal address:

Private Bag X6001,

Potchefstroom 2520,

South Africa

Dates:

Received: 24 Jan. 2014

Accepted: 16 July 2014

Published: 20 Nov. 2014

How to cite this article:

Wolhuter, C.C., Potgieter, F.J.

\& Van der Walt, J.L., 2014

'Modelle van interreligieuse

toleransie in die onderwys

van die een-en-twintigste

eeu', In die Skriflig 48(1),

Art. \#1798, 8 pages. http://

dx.doi.org/10.4102/ids.

v48i1.1798

\section{Copyright:}

(C) 2014. The Authors

Licensee: AOSIS

OpenJournals. This work

is licensed under the

Creative Commons

Attribution License.
Read online:

Scan this $Q R$ code with your smart phone or mobile device to read online.
Vir 'n toenemend multireligieuse samelewing en globaliserende wêreld behoort die opvoedeling, net soos in die verlede, voorberei te word vir saamleef met mense wie se religieuse oortuigings anders is as hulle eie. Die doel van hierdie artikel is om die belangrikste modelle van interreligieuse toleransie in terme van hulle bruikbaarheid in die onderwys te evalueer. Hierdie evaluering geskied aan die hand van die volgende maatstawwe: die struktuur en aard van religie en die plek daarvan in die lewe van die mens; die aard, doelstellings en reikwydte van onderwys; die toenemende diverse samestelling van samelewings; en die kontemporêre samelewingstendense van toenemende individualisering en pluralisering. Die hoofmodelle van interreligieuse verhoudings, naamlik eksklusivisme (sowel die sendingywer- as die laissez faire-variasies), inklusivisme, universalisme en ook die verskillende vorms van pluralisme, insluitende positiewe of dialogiese pluralisme, word aan hierdie maatstawwe gemeet. Op grond van die tekortkomings van hierdie modelle word 'n nuwe model, te wete 'n lewensbeskoulik(e) saamleef, vervolgens ontwikkel en voorgestel.

Models of interreligious tolerance for education in the 21st century. For an increasingly multi-religious society and globalised world, the educand should also be prepared for living with people who embrace religious beliefs that may differ from their own. The aim of this article is to evaluate the various models of interreligious tolerance in terms of their usefulness in education. This assessment takes place according to the following parameters: the nature and structure of religion and the place thereof in the lives of people; the increasingly diverse composition of societies; the contemporary societal trends of growing individualisation and pluralisation, and also the nature, aims and extent of education. The major models of interreligious relations are weighed up against these criteria, namely exclusivism (including both the missionary zeal and laissez faire variants), inclusivism, universalism as well as the various forms of pluralism, including positive or dialogical pluralism. On the basis of the deficiencies of these models a new model, namely world and life view co-existence, is then developed and suggested.

\section{Inleiding}

Die Suid-Afrikaanse onderwyslandskap is uit die staanspoor deur 'n eksplisiete Christelike grondmotief gekenmerk (Booyse, Roux, Seroto \& Wolhuter 2011). Hierdie soort onderwys is ten regte of ten onregte - in progressiewe kringe erg gekritiseer. Dit geld vir sowel die historiese Blanke onderwys (Christelik-nasionale onderwys; vgl. Malherbe 1977:47) as vir albei vorms van die destydse Swart onderwys, te wete sendingonderwys (cf. Wolhuter, Potgieter \& Steyn 2011) en die sogenaamde Bantoe-onderwys (cf. Behr 1988:110-111). Hierdie bedeling is de jure met die promulgering van die Godsdiens in Onderwys-beleid beëindig (South Africa 2003), waarvolgens 'godsdiens-neutrale skole' geskep is (vgl. Van der Walt, Potgieter \& Wolhuter 2010). Die Christelike etos het egter steeds de facto in baie skole tot vandag toe bly voortbestaan. In 'n land waar die meerderheid van die bevolking (80.9\%) hulself as Christene identifiseer, volgens die Pew Research Center se Global Christianity Survey (Pew Research Center 2011:74), sou dit seker beweer kon word dat religie-onderrig in tuisopvoeding ' $n$ monoreligieuse vorm van opvoeding is. Dit impliseer die oordrag en inskerping van die opvoeder se religieuse oortuigings by die kinders en die jongmense (in gehoorsaamheid aan die voorskrif in Deut 6:4). 'n Aanduiding van hoedanig onderwys in Suid-Afrika voor 1994 gekonseptualiseer was, is dat opvoedende onderwys in destydse opvoedkundige bronne omskryf word as lewensopvattingverwerkliking (vgl. Roos 1979), dit impliseer die oordrag van een bepaalde lewensopvatting (waarbinne 'n bepaalde religieuse oortuiging sentraal gestaan het) van een geslag na die volgende (vgl. ook Chidester 2006:264-265).

Die huidige beleidsrigtings oor religie in die onderwys in westerse lande (ook in Suid-Afrika) het daartoe gelei dat konfessionele religie-onderwys uit skole verwyder is en met geïntegreerde 
religie-onderwys vervang is; dit dui dus op religieonderwys waarin die leerders aan die hoofreligieë van die wêreld bekend gestel word (vgl. Hagesaether \& Sandsmark 2006; Loobuyck \& Franken 2011). Die doel van hierdie benadering is om ' $n$ sogenaamde interreligieuse begrip en verdraagsaamheid te kweek (cf. Van der Walt et al. 2010:31; Loobuyck \& Franken 2011:24; Wright 2004:191). In die breë projek van interkulturele onderwys ter wille van beter interkulturele verhoudings figureer die religiedimensie egter nie. Schweitzer (2006:89) kritiseer byvoorbeeld beleidsrigtings in Europa hieroor. Daar is volgens hom 'n behoefte om aan religie-onderwys sy regmatige integrale plek in die georganiseerde onderwys te verleen. Volgens Schweitzer (2006:98) is die model van 'neutrale geïntegreerde religie-onderwys' in skole nie die beste manier om dit te bewerkstellig nie. In Suid-Afrika stel die vraag oor die plek en die rol van religie-onderwys in georganiseerde onderwys (skole) die (Christelike) ouer en georganiseerde geloofsgroepe eweneens voor die uitdaging van hoe hulle vanuit die basis van konfessionele religie-opvoeding hulle kinders tot interreligieuse verdraagsaamheid behoort op te voed en te laat opvoed.

'n Toenemend multireligieuse samelewing en globaliserende wêreld verg dat opvoedelinge voorberei behoort te word vir die saamleef met mense wie se religieuse oortuigings anders is as hulle s'n. Die monoreligieuse opvoeding wat hierbo genoem is en wat eksklusief is (d.w.s. die oordrag van 'n bepaalde stel religieuse oortuigings met die oog op die persoonlike aanvaarding daarvan deur die kind of die jongmens), skyn hiermee in teenstelling te wees, of ten minste ' $n$ onvolledige opvoeding te wees in die lig van die toenemende eis van opvoeding tot die saamleef in 'n toenemend multireligieuse wêreld (Boeve 2000:250; Steyn \& Wolhuter 2008:16).

Die Godsdiens in Onderwys-beleid in Suid-Afrika stel die doel van die vak Godsdiensonderwys (waarin die leerder in die vak Lewensoriëntering aan die hoofreligieë van die wêreld bekend gestel word) as die kweek van interreligieuse toleransie (vgl. South Africa 2003). Hierdie diskoers word in die nuutste kurrikulumverklaring (die CAPS-dokument) voortgesit (vgl. South Africa 2011:8), maar nóg die 2003-dokument, nóg die nuutste kurrikulumverklaring (CAPS-dokument) verduidelik hierdie begrip.

Interreligieuse toleransie is ' $n$ begrip waaraan vele en uiteenlopende betekenisse geheg word. Die doel van die navorsing wat in hierdie artikel gerapporteer word, is om verskillende modelle van interreligieuse toleransie te ondersoek en te verduidelik en as modelle vir die onderwys te evalueer. Hierdie evaluering het aan die hand van die volgende drie maatstawwe geskied:

- die een-en-twintigste-eeuse samelewing, veral die twee eienskappe van toenemende multireligieuse samelewings en van individualisering;

- die aard van religie en die plek daarvan in die mens se lewe; en

- religie-onderwys as 'n vorm van opvoeding.
Die bespreking begin met 'n verduideliking van bovermelde drie komponente van die evalueringsraamwerk wat toegepas is. Dit word gevolg deur 'n verduideliking van die belangrikste modelle van religieuse toleransie wat in die bestaande literatuur aangetref word. Ten slotte word elkeen van die modelle aan die hand van hierdie evalueringsraamwerk beoordeel.

\section{Evalueringsraamwerk Toenemende diversiteit en individualisering in moderne samelewings}

Een van die kenmerke van die hedendaagse wêreld is die inligtings-, kommunikasie- en vervoerrevolusie (vgl. Steyn \& Wolhuter 2008:20-22). Hierdie revolusie maak toenemende bevolkingsmobiliteit moontlik. Die totale getal internasionale migrante (mense wat hulle in ' $n$ land bevind anders as die een waarin hulle gebore is) het die afgelope 10 jaar vanaf 150 miljoen tot 214 miljoen toegeneem (International Organisation for Migration 2012). Een uit elke 33 persone in die wêreld is dus vandag ' $n$ internasionale migrant. In ' $n$ tyd van globalisering en internasionalisering lei hierdie demografiese mobiliteit tot toenemend multikulturele samelewings. Australië en Kanada is voorbeelde van toenemend diverse samelewings wat eens baie meer homogene lande was met ' $n$ koloniale geskiedenis. Australië het sy 'Slegs blankes'-immigrasiebeleid al in 1967 laat vaar (O’Neill 2010:33). Een faset van kulturele diversiteit is religieuse diversiteit. Voor 1960 was 90\% van Kanadese immigrante uit Europa afkomstig; tans kom 58\% van Kanadese immigrante uit Asië en slegs 20\% uit Europa (Riddell-Dixon 2008:32). In Brittanje het die seminale Swann verslag alreeds 30 jaar gelede gewys hoe naTweede-Wêreldoorlogse immigrasiepatrone die demografie gediversifeer het en watter verreikende gevolge dit vir die onderwys, insluitende godsdiensonderwys, in daardie land het (Great Britain 1985). Die inligtings-, kommunikasieen vervoerrevolusie maak nie net fisiese mobiliteit moontlik nie, maar is ook 'n bemagtigingsinstrument vir minderheidsgroepe wat hulle eie ideale wil bevorder. Voorheen kon die regerings van nasionale state poog om minderheidsgroepe se kulture en ideale te onderdruk en sodoende die amptelik gesanksioneerde dominante kultuur op alle inwoners af te dwing. Kulturele diversiteit is indertyd as ' $n$ bedreiging vir sowel die nasionale eenheid as die integriteit en soewereiniteit van die nasiestaat met sterk gesentraliseerde magstrukture beskou (vgl. die situasie in Frankryk).

'n Tweede tendens in die hedendaagse wêreld is die verbrokkeling van die mag en soewereiniteit van die eens magtige nasiestaat en die sentrale regering van so 'n staat. Om die magsvakuum te vul, verskuif die lokus van mag na allerlei gedesentraliseerde strukture, naamlik streeks- of provinsiale regerings, plaaslike gemeenskappe en uiteindelik die vlak van die individu (vgl. Steyn \& Wolhuter 2008). Hierdie tendens word deur twee ander neigings in die hedendaagse wêreld aangehelp, te wete demokratisering en die reeds vermelde inligtings-, 
kommunikasie- en vervoerrevolusie. Hierdie twee neigings skep 'n verskeidenheid kanale vir ontspanning, inligting, onderwys en dies meer, met die gevolg dat mense wat selfs in dieselfde straatblok bly, radikaal verskillende tydverdrywe, gewoontes, waardes, ensovoorts mag hê. Die neo-liberale ekonomiese revolusie, tesame met die tegnologie wat individuele verbuikerspesifieke produkte kan lewer (customisation) en tot 'n kultuur van verbruikerisme (consumerism) lei, versterk boonop hierdie tendens van selfgesentreerdheid en individualisering in die hedendaagse wêreld, ook op die gebied van godsdiensbeoefening en -oortuigings (vgl. Engebretson 2003; Jackson 2004).

Dit sou onvanpas wees om 'n waarde-oordeel oor die wenslikheid al dan nie van al hierdie hedendaagse tendense en veranderings uit te spreek, hoofsaaklik omdat sodanige waarde-oordeel geen verskil aan die praktiese toedrag van sake sal maak nie. Of dit wenslik is of nie, die hedendaagse samelewing word deur kulturele en maatskaplike pluralisering, detradisionalisering (Boeve 2000:250), sekularisering, mark- en verbruikersgeoriënteerdheid, individualisme en personalistiese waarde-georiënteerdheid gekenmerk. Die vraag is dus hoe 'n skool sigself in hierdie omstandighede behoort te oriënteer.

\section{Die aard van religie}

Volgens Van der Walt et al. (2010:36) vertoon religieë die volgende basiese struktuur:

- Eerstens het religieë 'n buitenste waarneembare of rituele laag. Voorbeelde van rituele sluit in diensordes en roetines, gebed, lees uit heilige boeke, eerbetoon by altare, in kerke, moskees, sinagoges, ensovoorts.

- Religieë word ook deur 'n respek vir 'n god of gode gekenmerk. Sommige religieë werk met 'n vaste en pertinente godsbegrip, terwyl die godsbegrip van andere meer verskuil is; selfs tot so 'n mate dat 'n mens sou kon dink dat hulle geen godsbegrip het nie. Materialisme is so ' $n$ religie; die aanhanger is in hierdie geval verbind tot 'n oorsprong of beginsel, te wete materiële besitting. Alle religieë bevat die een of ander spiritualiteit, dit wil sê geestelike verbintenis of binding aan die een of ander oorsprong of archē.

- Religieë het ook 'n dogmatiese laag.

- Religieë vertoon 'n filantropiese of omgee-karakter.

- 'n Pistiese laag is ook deel van religieë, naamlik die geloof en vertroue in 'n transendentale mag wat nie direk waargeneem kan word nie.

- Op die diepste vlak het religieë ook 'n spirituele dimensie. Spiritualiteit (wat ook in die humanistiese religieë waarna hierbo verwys is, voorkom) het met die mens se soeke na betekenis, sin, diepte en waardes te make. Dit is die mistieke dimensie van religie en gaan oor 'n belewenis van wees-in en verbind-wees aan die ganse werklikheid (heelal, kosmos) wat gevul is met skoonheid, misterie en betekenis. Volgens Hollick (2006) gaan spiritualiteit ook oor die oorskouing van die probleme en aangeleenthede van die lewe vanuit 'n hoëre, verligte, sintetiese vlak.
Die vermelde individualiseringstendens kom ook toenemend in die religieverband na vore (vgl. Schweitzer 2006). In plaas daarvan om die dogma van 'n bepaalde (Christelike of ander) denominasie volledig te onderskryf, is daar ' $n$ neiging onder mense dat individue hulle eie stel geloofsoortuigings formuleer. Daar is al na hierdie verskynsel as kafeteria-Christenskap verwys (Engebretson 2003:11) - mense selekteer self uit die leer van die verskillende konvensionele religieuse denominasies in watter elemente hulle wil glo, in plaas daarvan om volledig of eksklusief die volgeling van één bepaalde denominasie of religieuse stroming te word. Hierdie verskynsel vorm deel van die kulturele dinamiek van die hedendaagse samelewing soos die etnografiese navorsing van Gerd Baumann oor religieuse diskoerse in gemeenskappe in Engeland aangetoon het (Jackson 2004:7-8). Kultuur word nie meer as ' $n$ fotokopieermasjien beskou nie; in ' $n$ plurikulturele omgewing skep individue hulle eie kulture, insluitend religieuse kulture. Mense skryf nie meer 'n standaard religiebiografie nie; almal skryf hulle eie een (Miedema 2006:120, 121). Sonder om die groepskarakter van religie te ontken, neem huidige pedagogieke slegs dit van religiekategorieë, byvoorbeeld van Moslem of Sihk, wat as verwysingspunte kan dien ter beskrywing en bestudering van 'n onderliggende realiteit wat baie meer divers, kompleks en dinamies is (Jackson 2004). Volgens Jackson (2004:8) maak dit die opvoedingsopgawe van die opvoeder meer kompleks, maar ook meer geleentheidsryk: die eindelose getal individuele permutasies van die elemente van die verskillende godsdienstige oortuigings beteken dat daar meer as ooit tevore teen die stereotipering van aanhangers van ander godsdienste gewaak moet word. Die individuele vorming van 'n eie godsdiens skep meer geleentheid as ooit tevore om die opvoedeling tot kritiese denke en standpuntvorming rondom godsdienstige en verwante waarde-oortuigings te begelei.

Dit sou hier ook onvanpas wees om 'n waarde-oordeel te vel, aangesien 'n uitspraak oor die wenslikheid en die normatiewe aanvaarbaarheid van die verskynsel van religieuse diversiteit geen verskil aan die voorkoms daarvan in die wêreld sal maak nie. Die groeiende sekularisering (losmaak van die geïnstitusionaliseerde kerk), sekularisme (losmaak van religie in die algemeen), religieuse pluralisme, dekonfessionalisering, 'n groeiende Christelike humanisme en toenemende algemene waardegeoriënteerdheid is almal verskynsels wat gekom het om te bly. Onderwysbeleidmakers moet ' $n$ manier vind om hulle te hanteer (vgl. Van der Walt \& Wolhuter 2005).

\section{Onderwys en die plek van religie-opvoeding en -onderwys daarin}

UNESCO (2014:4) omskryf onderwys as 'kommunikasie wat daarop gerig is om leer te bewerkstellig'. Op grond van 'n uitgebreide literatuurstudie en refleksie kom Potgieter (2014:33) tot die gevolgtrekking dat opvoeding begeleiding is wat 'n volwasse persoon (opvoeder) aan 'n nie-volwasse persoon (opvoedeling) verskaf ten einde die opvoedeling in staat te stel om tot 'n persoon te vorder wat: 
- 'n sinvolle lewe kan lei;

- tussen reg en verkeerd en tussen goed en sleg kan onderskei;

- op grond van hierdie onderskeiding kan optree, selfs ten koste van die self; en wat

- verantwoordelikheid vir sodanige optrede kan neem.

Religie vorm ' $n$ kernaspek van die lewe en die funksionering van die mens, aangesien dit vier funksies in die lewe van individue en in samelewings vervul. Hierdie funksies sluit in die betekenisgewing aan die lewe en aan die wêreld, identiteitskepping, die skep van 'n gemeenskaplike etiek in 'n samelewing (Boeve 2000:254) en die ondersteuning in die hantering van die eise van die lewe en die wêreld (Proux 2007:6). Hoe onontbeerlik religie in die vervulling van hierdie funksies is, blyk uit die feit dat die meeste mense in die wêreld die een of ander vorm van religie aanhang (in die breë betekenis van die term, soos hierbo verduidelik). Al mag die dalende kerkbywoningsyfers byvoorbeeld gronde verskaf vir die argument dat die hedendaagse wêreld al meer 'n postreligieuse tydperk binnegaan, kan statistiek aangehaal word om te argumenteer dat baie mense wel religieus bly, al beoefen hulle in die era van geïndividualiseerde religie nie meer religie in 'n geïnstitusionaliseerde vorm nie (Hendrikse 2011:194). Die syfers in Tabel 1, uit opnames onder volwassenes in Nederland, word genoem om hierdie stelling te staaf (persentasie response):

Ten spyte van die feit dat Nederland in 'n groot mate 'n kerklose samelewing geword het (met 'n al kleiner persentasie mense wat die kerk gereeld besoek, vgl. Hendrikse 2011:194), bly die persentasie mense met religieuse oortuigings steeds betreklik hoog. In Australië het Engebretson (2003:10-11) se navorsing onder RoomsKatolieke adolessente eweneens bevind dat alhoewel belangstelling in die geïnstitusionaliseerde religie in Australië daal, daar tog 'n toenemende hunkering na persoonlike spirituele belewenisse bestaan.

In hierdie geval kan 'n waarde-oordeel wel uitgespreek word. Die onderwys moet altyd opvoedend van aard wees, met ander woorde dit moet die kind of jongmens vir die toekoms (bege-)lei, vorm en toerus (vgl. Verloop \& Lowyck 2003:44-51). Tydens hierdie gebeure mag die religieuse faset van die kinder- of jongmenslewe nie geïgnoreer word nie. In 'n kultuur en samelewing wat deur diversiteit gekenmerk word, kan die religieuse invloede wat van die opvoeder na die kind of jongmens uitgaan nie meer eenduidig wees soos in monoreligieuse samelewingskontekste nie. Dit is juis om hierdie rede dat daar na modelle van religieuse toleransie

TABEL 1: Religieuse ingesteldheid van Nederlandse volwassenes.

\begin{tabular}{lllll}
\hline Vraag: Glo jy in lewe na die dood? & $\mathbf{1 9 6 6}$ & $\mathbf{1 9 7 9}$ & $\mathbf{1 9 9 6}$ & $\mathbf{2 0 0 6}$ \\
\hline Ja & 56 & 41 & 45 & 40 \\
Nie seker & 8 & 19 & 22 & 31 \\
Nee & 36 & 40 & 33 & 29 \\
\hline Totaal & 100 & 100 & 100 & 100 \\
\hline
\end{tabular}

Source: Hendrikse, K., 2011, God bestaat niet en Jesus is zijn zoon, Nieuw Amsterdam Uitgevers, Amsterdam gesoek behoort te word. Hierdie modelle moet aan die vereistes van mense met verskillende religieuse oortuigings, behoeftes en ideale kan voldoen.

\section{Modelle van interreligieuse toleransie}

Die versameling modelle van interreligieuse toleransie wat in die literatuur aangetref word, word skematies in Figuur 1 voorgestel:

Die eerste verdeling tussen die modelle is dié van eksklusivisme, inklusivisme en pluralisme.

\section{Eksklusivisme}

Persone met ' $n$ eksklusivisitiese standpuntinname oor hulle eie geloof of religie versus dié van ander, beskou hulle eie religie of geloofsoortuigings as die enigste waarheid en enigste korrekte leefwyse (Cush 1994). Aangesien die eie geloof volgens hulle die absolute waarheid bevat, word alle ander religieë as vals beskou (Vermeer \& Van der Ven 2004:39).

In die klas van eksklusivisme kan twee ideaaltipes (met 'n spektrum van moontlikhede tussenin) onderskei word. Die eerste is waar daar met ' $n$ sendingywer gepoog word om aanhangers van ander gelowe na die eie oortuiging te bekeer. Die tweede is waar aanhangers van ander religieë heeltemal geïgnoreer word, met 'n gesindheid van laat staan of laat hulle alleen. Dit is insiggewend dat Schweitzer (2006:93) in sy navorsing oor geïndividualiseerde religie onder die hedendaagse jeug in Duitsland bevind dat hierdie tipe tans die dominante gesindheid onder die jeug in Duitsland is, afgesien van die godsdiens wat hulle of hulle ouers voorheen aangehang het.

\section{Inklusivisme}

Inklusiviste probeer om aansprake wat met die eerste oogopslag na teenstellende aansprake op die waarheid of die regte manier om te lewe, lyk, tot een inklusiewe stelsel

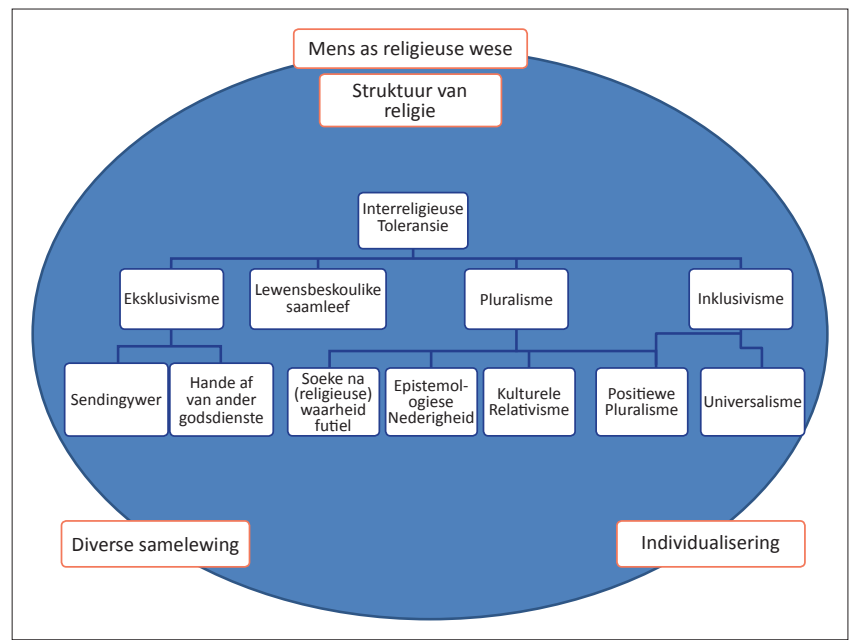

FIGUUR 1: Modelle van interreligieuse toleransie. 
te versoen en saam te snoer (Cush \& Francis 2006:52). Universalisme is 'n ekstreme vorm van inklusivisme. Hier word aangevoer dat alle geloofstradisies essensieel of in hulle einddoelstelling dieselfde is (ibid.). 'Die Hindoese geloofsopvatting dat alle religieë paaie na dieselfde bonatuurlike wêreld is, is 'n sprekende voorbeeld. In minder ekstreme vorms word ander religieë in terme van die eie geloof beskou. Die oorsprong van ander religieë word óf uit die eie religie afgelei, óf ander religieë word as onvolledig beskou en dat hulle hulle vervulling in die eie religie behoort te bereik (Vermeer \& Van der Ven 2004:40). Die Islamitiese beskouing van Jesus Christus as een van die ry groot profete, wat chronologies kulmineer in die Profeet Mohammed as die laaste en die grootste (cf. Esposito 1988:15) is hiervan 'n voorbeeld. Nog 'n voorbeeld hiervan is Rahner (1962) se stelling rakende anonieme Christene, naamlik dat die nieChristelike geloofstradisies almal fasette van die Christelike geloofskat bevat en dat hulle aanhangers dus almal, in 'n sekere sin, anonieme Christene is (sg. sintesedenke).

\section{Pluralisme}

'n Pluralistiese ingesteldheid is een van verdraagsaamheid teenoor die verskillende religieë en van erkenning dat verskillende aansprake op die religieuse waarheid geldig mag wees. Pluraliste bou hulle standpunt nie so seer op die beginsel van die objektiewe waarheid nie, maar eerder op individue se subjektiewe belewenis van hulle eie geloof.

Ten minste drie vorms van pluralisme kan onderskei word. Die eerste is daardie pluraliste wat op grond van die premisse van die futiliteit van die soeke (met behulp van byvoorbeeld die wetenskaplike metode) na die objektiewe religieuse waarheid 'n filosofie van erkenning en toleransie van ander se geloofsoortuigings bou. Die volgende is diegene wat die standpunt van epistemologiese nederigheid handhaaf en aanvoer dat elke mens se kennis beperk, onvolledig of onvolmaak is en dat niemand dus daarop kan aanspraak maak dat die volle waarheid kenbaar sou wees nie (Cush \& Francis 2006:53). Kulturele relativisme voer op sy beurt aan dat mense se religieuse oortuigings kontekstueel bepaal of medebepaal word en dat daar gevolglik vir 'n verskeidenheid religieuse standpunte voorsiening gemaak behoort te word (cf. Kruger, Lubbe \& Steyn 2012:3-4, 5, 25). Daar is voorts ook positiewe pluralisme (ook genoem dialogiese pluralisme), wat in die rigting van inklusivisme neig. Eerder as om diversiteit as 'n probleem te beskou, verwelkom positiewe pluralisme diversiteit as 'n leergeleentheid (Cush \& Francis 2006:54). Die positiewe pluralisme vra vir interreligieuse dialoog ter verryking van die verskillende religietradisies (Vroom 2001:18-19). Dit erken en gee aandag aan pluraliteit binne die hoofstroomreligieë en nie net tussen die verskillende religieë nie (Cush \& Francis 2006:54). Wat die onderwys betref, impliseer positiewe pluralisme 'n beleid en praktyk van nie-konfessionele onderwys en religie-onderrig. Alle leerders behoort saam onderrig te word eerder as in afsonderlike religiegroepe. Hiervolgens is leerders dan vry tot kritiese denke, selfverkenning en die ontwikkeling van hulle eie geloof en waardes met betrekking tot die uitdagende vraagstukke waarmee alle religieë handel (Cush \& Francis 2006:54).

Die laaste opsie in Figuur 1, naamlik dié van lewensopvatlike saamleef, sal na die evaluering van al die bovermelde modelle verduidelik word.

\section{'n Evaluering van die vermelde modelle}

Eksklusivisme as variant (gebaseer op 'n oordrewe sendingywer) is nie te versoen met die samelewingstendens van toenemende individualisering ('n tendens wat hom ook op die religiegebied manifesteer) en van toenemende diverse samelewings (wat op die leer van menseregte gebou is) nie. Hierdie samelewingstendens sluit onder andere geloofsvryheid in soos duidelik uitgespel word in die Suid-Afrikaanse Handves van Godsdiensregte en -Vryhede (South African Charter of Religious Rights and Freedoms n.d.:2-3; vgl. Miedema 2006:124-125; Prinsloo 2008:27, 264, 419). Hierdie variant (in sy mees radikale vorm waar geweld as geregverdig beskou word om die eie geloofsoortuigings op ander af te dwing) is ook nie met die filantropiese (die omgee vir ander) dimensie van religie te rym nie. Wat die laissez faire-variant van eksklusivisme betref, moet dit gestel word dat die algemene postulaat dat religie waterdig van ander samelewingsisteme en -aspekte (bv. die politieke, sosiale, ekonomiese, hiërargie van waardes, ens.) geskei kan word, onhaalbaar is (vgl. Wolhuter 2012; Coetzee 2012). Een van die funksies van religie is die skep van 'n gemeenskaplike etiek. Sosiale kapitaal is nodig vir die bestaan en die voortbestaan van die mens in die globaliserende samelewing van die eenen-twintigste eeu met sy eiesoortige vraagstukke soos die omgewingskrisis, vooroordele teen bepaalde kategorieë mense of geweld en terreur. Om sodanige sosiale kapitaal te skep, is 'n dialoog nodig wat in die een of ander religieuse oortuigingsraamwerk gefundeer is.

Die strewes van inklusivisme en universalisme in die besonder, blyk ook in teenstelling te wees met die huidige tendens ('n onvermydelike gegewe) van individualisering en by implikasie ' $n$ al groter diversiteit in religieuse oortuigings. Dit skyn ook ooridealisties te wees in 'n wêreld waar interreligieuse konflik (insluitende gewelddadige interreligieuse konflik) volop is. Die feit dat die versameling religieuse oortuigings en hulle aanhangers se beskouings van mekaar bloot té ongelykvormig is om in een skema vas te vat, spreek duidelik uit 'n publikasie van Gort, Jansen en Vroom (2006) waarin aanhangers van die verskillende hoofreligiestromings in die wêreld hulle sienings uiteensit.

'n Pluralistiese standpunt wat op die gedagte van die futiliteit van die soeke na religieuse waarheid sentreer en wat sigself gevolglik van enige interreligieuse dialoog afsluit, loop dieselfde gevaar as die laissez faire-vorm van eksklusivisme, naamlik dat dit 'n verantwoordelike en volledige deelname aan die maatskaplike vraagstukke en 
uitdagings van die een-en-twintigste eeu onmoontlik maak. 'n Gesindheid van epistemologiese nederigheid hou op sy beurt waarskynlik nie behoorlik rekening met die sterk houvas wat 'n individu se religieuse oortuigings op sigself het nie - dit is eenvoudig te veel om te verwag dat hulle (die self en die ander) hulle hele geloofsoortuiging (al die lae in die struktuur van religie soos dit vantevore bespreek is) op die altaar van interreligieuse en intergroepsbetrekkings sal plaas (vgl. ook die besware wat vanuit die kant van geloofsgroepe teen die huidige godsdiensbeleid in SuidAfrikaanse skole aangeteken is; Chidester 2006:266-275).

Wat kulturele relativisme betref, kan gestel word dat 'n verabsolutering van hierdie uitgangspunt beteken dat 'n mens nie tydens 'n dialoog oor aktuele maatskaplike vraagstukke op jou geloofstandpunt kan terugval nie. Die meeste vorms van religiebeoefening het immers sekere kulturele wortels. 'n Ongebreidelde kulturele relativisme kan beteken dat 'n individu selfs die grootste vergrype en gruweldade (soos omgewingsvervuiling of die mishandeling van vroue en kinders) moet kondoneer, omdat dit in ooreenstemming is met die sogenaamde religieuse oortuigings van die betrokke daders.

Wat die standpunt van positiewe pluraliteit betref, geld dieselfde beswaar as wat teen epistemologiese nederigheid geopper is. In die lig van die sterk krag wat religie in die lewe van baie gelowiges is en die feit dat die diepere lae van religie (bv. die pistiese of die spirituele) moeilik deur middel van rasioneel kritiese logika of wetenskaplike metodes ondersoek kan word, mag dit vir baie mense te veel gevra wees om hulle volledige geloofspakket vir 'n interreligieuse kritiese dialoog oop te stel. Wanneer daar spesifiek op die voorstanders van hierdie model se leer oor religie-onderrig aan kinders gefokus word, duik nog 'n probleem op. Schweitzer en Boschki (2004) se navorsing oor die verwerwing van religieuse identiteit deur prepuberteitskinders (ouderdomsgroep 7 tot 9 jaar) in Duitsland, waar religieuse denominasies toegelaat word om die religie-onderrig in staatskole aan te bied, is insiggewend. Die navorsing toon aan dat kinders met 'n volwassene wat 'n bepaalde religie aanhang en onderrig, identifiseer ('Ek is Katoliek, ek hoort by mnr $X^{\prime}$ ). Hulle kom tot die gevolgtrekking dat vir sodanige identifikasie om te kan voltrek, die kind die geleentheid gegun moet word om genoegsame tyd by 'n onderwyser van dieselfde denominasie of lewensuitkyk as die kind deur te bring.

Aangesien nie een van die bovermelde modelle suksesvol aan al drie die toetsmaatstawwe wat aangelê is (die aard van religie, die samelewingstendense van diversiteit en individualisering), kon voldoen nie, behoort 'n ander model voorgestel te word. Hiervan word trekke weliswaar verspreid in die literatuur gevind, maar dit word nêrens volledig as 'n model uitgespel nie. Hierdie model is dié van lewensbeskoulik(e) saamleef (vgl. Figuur 1). Hierdie model kan moontlik as die religie-onderwyskeerkant van die huidige teorie van Interkulturele Onderwys beskou word.
Sedert die groei van multikulturele samelewings vanaf die einde van die Tweede Wêreldoorlog in WesEuropa momentum begin opbou het, het die teorie van multikulturele onderwys deur 'n reeks fases beweeg. Eers is leerders deur middel van 'n bykomstigheid in die gewone skoolkurrikula (wat die meerderheidskultuur gereflekteer en oorgedra het) aan die dominante of meerderheidskultuur van ander (minderheidskulture) voorgestel. Uit besorgdheid oor kommerwekkende xenofobiese aanvalle en interkulturele konflik, het die multikulturele onderwys in 'n volgende fase van antirassistiese onderwys verstrengel geraak (vgl. Leicester 1992; Tianlong 2012). In 'n verdere fase het dit met anti-onderdrukkingsonderwys (anti-oppressive education) vermeng. Dit het gebeur te midde van die toenemende klem wat Opvoedkunde-deeldissiplines soos die Sosiologie van die Opvoedkunde en die Vergelykende Opvoedkunde op die ongelyke magsverhoudings in die samelewing geplaas het (vgl. Kumashiro 2002; Kelly \& Brandes 2010). In die tydperk na 09 September 2011 en binne die konteks van toenemende globalisering, het die multikulturele onderwys in 'n fase van interkulturele onderwys gekulmineer (Wolhuter 2012:178). Interkulturele onderwys omvat elemente van antirassistiese onderwys, kritiese multikulturalisme (vgl. May 1999; Brantmeier, Aragon \& Folkestad 2011) en reflektiewe multikulturalisme (vgl. Rattansi 1992; Spatt, Honigsfeld \& Cohan 2012). Markou (1997) verduidelik die vier basiese beginsels van interkulturele onderwys soos volg:

- Onderwys met empatie, met ander woorde met 'n diep begrip vir ander en die inleef in hulle situasies.

- Onderwys in solidariteit, wat daarop dui dat 'n appèl op die kultivering van 'n kollektiewe gewete en die bevordering van sosiale geregtigheid gerig word.

- Onderwys vir interkulturele respek.

- Onderwys vir etiese denke en dialoog.

Waar multikulturalisme en multikulturele onderwys gaan om die erkenning van diversiteit en verdraagsaamheid teenoor verskille, gaan interkulturalisme en interkulturele onderwys verder as die blote passiewe vreedsame naasbestaan; dit gaan oor tot die bevordering van dialoog ten einde volgehoue vreedsame naasbestaan moontlik te maak (UNESCO 2006:15-16), met die leer van Menseregte soos veral in die Verenigde Nasies se Universele Handves van Menseregte geformuleer is as ' $n$ belangrike rigsnoer (UNESCO 2006:20-25).

Verbesonder tot die gebied van die religie, kan bogenoemde 'n eerbied vir en empatie met die geloofsoortuigings van ander en 'n dialogiese interaksie met hulle oor etiese vraagstukke beteken. Wat religie-onderwys betref, kan by Schweitzer en Boschki (2004) se navorsingsresultate aangesluit word wat alreeds bespreek is. Die bevinding van Van der Walt et al. (2010) op grond van hulle evaluering van religie-onderrigmodelle teen die agtergrond van die struktuur en wese van religie, vind ook hierby aansluiting, naamlik dat dit die beste model is om die leerder in die vroeë lewensfases te onderrig in een religie, deur 'n beoefenaar van daardie betrokke religie. Deur sodanige eerstehandse 
belewing van die religie en die plek daarvan in ' $n$ mens se lewe en vanuit daardie geborgenheidsruimte, kan die leerder dan tydens ' $n$ later fase aan ander religieë voorgestel word en met aanhangers van ander religiegroeperings in 'n dialogiese gesprek geplaas word (ibid. 2010:45).

Vanuit die basis van die eie religie behoort die leerder onderrig te word om verdraagsaamheid, respek en empatie vir ander religieë te kweek. Indien bovermelde struktuuranalise van religie aanvaar word, kan sodanige verdraagsaamheid ontwikkel word deur 'n appèl tot die filantropiese (omgee-) en spirituele lae van religieë te rig. In terme van die Christelike geloof, het Johannes Lähnemann en medewerkers in 1998 byvoorbeeld 'n benadering, bekend as die Nürenberger Forum, ontwikkel van hoe die religieuse gronde vir toleransie vanuit elemente van die Christelike geloof en vanuit die Bybel gevind kan word (Jackson \& Fujimore 2007:4). Insgelyks, deur 'n appèl tot die filantropiese en spirituele lae van ander religieë te rig, kan 'n interreligieuse gesprek oor etiese vraagstukke plaasvind.

'n Saak kan daarvoor uitgemaak word dat die model van lewensbeskoulik(e) saamleef tipies van 'n 'sagte foundationalistiese' uitgangspunt is. Aan die een kant vermy so 'n uitgangspunt die eenselwigheid van 'n modernistiese of foundationalistiese benadering waarin daar van die veronderstelling uitgegaan is dat alle redelike (rasionele, denkende) mense op 'n sekere standaard- of geykte manier oor sake dink soos die religie en die onderwys. Aan die ander kant vermy dit die relativisme van 'n postmoderne (of sogenaamde postfoundationalistiese) benadering in terme waarvan geen vaste (religieuse) waardes of beginsels erken word nie. Die model van lewensbeskoulik(e) saamleef is in die erkenning gefundeer dat die werklikheid lewensbeskoulik divers geraak het en dat 'n mens daarmee moet saamleef. In hierdie diversiteit staan die wesenlike van die eie religie en lewens- en wêreldbeskouing sentraal (Boeve 2000:251). Die grondimplikasie hiervan is dat daar vir die eie religie en lewens- en wêreldbeskouing 'n regmatige plek in die diversiteit van religieuse sienings gesoek behoort te word. Die model van lewensbeskoulik(e) saamleef erken die werklikheid van sekularisering en van diversiteit, sowel binne as buite 'n skool. Dit soek na weë om die eie (bv. Christelike) geloof midde-in die vermelde samelewings- en kulturele omstandighede herkenbaar te maak in die veronderstelling dat dit, soos Boeve dit stel, 'n relevante sinaanbod kan maak. Almal wat by die (Christelike) skool betrokke is, word aangemoedig om na binne en buite dialoog te voer en by geleentheid ook in konfrontasie met die eie en ander gelowe en religieë te gaan.

Die model van lewensbeskoulik(e) saamleef gaan nie uit van die tradisionele kontinuiteit tussen die onderwys, die kultuur en die samelewing nie; dit gaan eerder uit van die diskontinuïteit tussen hierdie entiteite. Dit aanvaar dat die eie geloof (die Christelike) maar net een geloof te midde van 'n veelheid gelowe in 'n pluralistiese samelewingsopset is. Volgens hierdie model behou 'n onderwysinstansie soos 'n skool sy eie karakter en identiteit, maar erken die werklikheid van sekularisering, detradisionalisering en pluralisering sowel binne die skool as daarbuite in die samelewing en die kultuur. Die (Christelike) skool word 'n plek vir herbesinning oor die eie geloof en religie en vir die voer van dialoog met die lewensbeskoulike pluraliteit. Dialoog word in hierdie model 'n maatskaplike roeping; almal behoort by die maatskaplike debat betrokke te raak. Een van die gronddoelstellings van religie-onderwys, volgens hierdie model, is om kinders en jongmense te onderrig om met religieuse en lewensbeskoulike verskille, met andersheid, om te gaan en om andersheid nie as bedreigend te ervaar nie, maar dit eerder as 'n geleentheid tot bevraging en verryking (Boeve 2000:255-256) te beskou.

\section{Slot}

Aangesien nie een van die konvensionele modelle van interreligieuse toleransie wat aan die vereistes, gemeet aan die struktuur van religie en die plek daarvan in die lewe van die mens aan die een kant en die aard van die een-entwinstigste-eeuse samelewing aan die ander kant, voldoen nie, is 'n nuwe model, naamlik dié van lewensbeskoulik(e) saamleef, voorgestel. Die model van lewensbeskoulik(e) saamleef is op die beginsels van interkulturele opvoeding en onderwys gebou en gee rekenskap van die belangrikheid van die eie religie en lewensbeskouing te midde van die detradisionalisering, sekularisering en diversifisering in die samelewing en die kultuur.

\section{Erkenning Mededingende belange}

Die outeurs verklaar dat hulle geen finansiële of persoonlike verbintenis het met enige party wat hulle nadelig kon beïnvloed in die skryf van hierdie artikel nie.

\section{Outeursbydrae}

F.J.P. (Noordwes-Universiteit) was die projekleier. C.C.W. (Noordwes-Universiteit) was vir die konseptualisering van hierdie navorsing verantwoordelik. J.L.v.d.W. (NoordwesUniversiteit) was verantwoordelik vir die inisiëring van die metodologiese en epistemologiese besteiering van die artikel self, sowel as vir die opskryf van die aanvanklike konsepweergawe daarvan. Die taakverdeling met betrekking tot die literatuur-opsporing en -verwerking, asmede die konseptualisering van die voorlopige artikel, was egter min of meer gelykop tussen J.L.v.d.W., C.C.W. en F.J.P. F.J.P. was vir die opstel van alle finale weergawes van die artikel (voor en sedert indiening) verantwoordelik, sowel as vir alle redaksionele wysigings.

\section{Verwysings}

Behr, A.L., 1988, Education in South Africa: Origins, issues and trends: 1652-1987, Academica, Pretoria.

Boeve, L., 2000, “'Katholieke” universiteit: Vir denkpistes', Ethische Perspektieven 10(4), 250-258. http://dx.doi.org/10.2143/EPN.10.4.504077

Booyse, J.J., Le Roux, C.S., Seroto, J. \& Wolhuter, C.C., 2011, A history of schooling in South Africa, Van Schaik, Pretoria. 
Brantmeier, E.J., Aragon, A. \& Folkestad, J., 2011, 'Examining collaborative learning modalities (CLM): Critical multicultural education', Multicultural Education \& Technology 5(1), 5-18. http://dx.doi.org/10.1108/17504971111121892

Chidester, D., 2006, 'Religion education in South Africa: Teaching and learning about religion, religions and religious diversity', British Journal of Religious Education 25(4), 261-278. http://dx.doi.org/10.1080/0141620030250402

Coetzee, M., 2012, 'You are what you think', The Citizen, 29 November, p. 12.

Cush, D., 1994, 'A suggested typology of positions on religious diversity', Journal of Beliefs and Values 15(2), 18-21. http://dx.doi.org/10.1080/1361767940150205

Cush, D. \& Francis, D., 2006, “"Positive pluralism” to awareness, mystery and value: A case study in religious education curriculum development', British Journal of Religious Education 24(1), 52-67. http://dx.doi.org/10.1080/0141620010240106

Engebretson, K., 2003, 'Young people, culture and spirituality: Some implications for 'the ministry', Religious Education 98(1), 5-24. http://dx.doi. implications for the ministry"
org/10.1080/00344080308297

Esposito, J.L., 1988, Islam: The straight path, Oxford University Press, Oxford.

Gort, J.D., Jansen, H. \& Vroom, H.M. (eds.), 2006, Religions view religions, Rodopi, Amsterdam.

Great Britain, 1985, Education for all: The report of the Commission of Inquiry into the Education of Children of Minority Groups, HMSO, London.

Hagesaether, G. \& Sandsmark, S., 2006, 'Compulsory education in religion - The Norwegian case: An empirical evaluation of RE in Norwegian schools, with a special
focus on human rights', British Journal of Religious Education 28(3), 275-287. http:// focus on human rights', British Journal of
dx.doi.org/10.1080/01416200600811402

Hendrikse, K., 2011, God bestaat niet en Jesus is zijn zoon, Nieuw Amsterdam Uitgevers, Amsterdam.

Hollick, M., 2006, The science of oneness, O Books, Winchester.

International Organisation of Migration, 2012, Facts and figures, viewed 03 Septembe 2012, from http://www.iom.int/jahia/Jahia/about-migration/facts-and-figures/lang/ en

Jackson, R., 2004, 'Intercultural education and recent European pedagogies of religious education', Intercultural Education 15(1), 3-14. http://dx.doi. org/10.1080/1467598042000189952

Jackson, R. \& Fujimore, S., 2007, 'Towards religious education for peace', British Journa of Religious Education 29(1), 1-16. http://dx.doi.org/10.1080/01416200601093521

Kelly, D.M. \& Brandes, G.M., 2010, “'Social justice needs to be everywhere”: Imagining the future of anti-oppression education in teacher preparation', Alberta Journal of Educational Research 56(4), 388-402.

Kruger, J.S., Lubbe, G.J.A. \& Steyn, H.C., 2012, The human search for meaning: A multireligion introduction to the religions of humankind, 2nd edn. Van Schaik, Pretoria.

Kumashiro, K., 2002, Troubling education: Queer activism and anti-oppressive pedagogy, Routledge, New York.

Lähnemann, J., 1998, Evangelische Religionspädagogik in interreligiöser Perspektive Vandenhoeck \& Ruprecht, Göttingen.

Leicester, M., 1992, 'Antiracism versus new multiculturalism moving beyond the interminable debate', in J. Lynch, C. Modgil \& S. Modgil (eds.), Cultural diversity and the schools: Equity and excelence? Education and cultural reproduction, pp. 215-230 Falmer, London.

Loobuyck, P. \& Franken, L., 2011, 'Towards integrative religious education in Belgium and Flanders: Challenges and opportunities', British Journal of Religious Education 33(1), 17-30. http://dx.doi.org/10.1080/01416200.2011.523517

Malherbe, E.G., 1977, Education in South Africa, vol. 2: 1923-1975, Juta, Cape Town.

Markou, G., 1997, Introduction to intercultural education, Pappas Bros, Athens.

May, S., 1999, Critical multiculturalism: Rethinking multicultural and anti-racist education, Falmer, London.

Miedema, S., 2006, 'Public, social and individual perspectives on religious education: Voices from the past and the present', Studies in Philosophy and Education 25(2), 111-127. http://dx.doi.org/10.1007/s11217-006-6433-z

O'Neill, M., 2010, 'Forty years on: Education for a culturally diverse Australia', in C.C. Wolhuter \& H.J. Steyn (eds.), Education and ethnicity: Comparative perspectives/ Education and éthnicité: Perspectives compares, pp. 33-57, Platinum Press, Potchefstroom

Pew Research Center, 2011, Global Christianity, viewed 23 June 2014, from http:// www.pewforum.org/files/2011/12/Christianity-fullreport-web.pdf

Potgieter, F.J., 2014, 'Considering a pedagogy of discernment as primus inter pares: Implications for Comparative Education', in N. Popov, C. Wolhuter, K.S. Ermenc, G. Hilton, J. Ogunleye \& O. Chigisheva (eds.), Education's role in preparing globally competent citizens, pp. 32-38, Bulgarian Comparative Education Society, Sofia.
Prinsloo, P., 2008, 'A critical evaluation of the South African policy on religion and education (2003)', Unpublished doctoral thesis, Faculty of Education, University of South Africa.

Proux, J., 2007, 'Is religion on the rise or on the decline? A brief sociometric portrait of religion in Quebec', Canadian American Research Series 4(1), 6-9.

Rahner, K., 1962, 'Das Christentum und die nichtchristlichen Religionen', in K. Rahner (Hrsg.), Schriften zur Theologie, vol. 5, pp. 36-158, Benzinger, Einsiedeln.

Rattansi, A., 1992, 'Changing the subject: Racism, culture and education', in J. Donald \& A. Rattansi (eds.), Race, Culture and Difference, pp. 11-48, Sage \& the Open University Press, London.

Riddell-Dixon, E., 2008, 'Assessing the impact of recent immigration trends on Canadian foreign policies', in D. Carment \& D. Bercuson (eds.), The world in Canada: Diaspora, demography and domestic policies, pp. 31-49, McGills University Press, Montreal.

Roos, S.G., 1979, 'Opvoeding as lewensopvattingverwerkliking', in W.A. Landman, S.G. Roos \& N.J. Mentz (reds.), Fundamentele pedagogiek: Leerwyses en vakonderrig, bl. 69-83 Butterworths, Durban.

Schweitzer, F., 2006, 'Religious individualization: New challenges to education for tolerance', British Journal of Religious Education 29(1), 89-100. http://dx.doi. org/10.1080/01416200601037551

Schweitzer, F. \& Boschki, R., 2004, 'What children need - Co-operative religious education in German schools: Results from an empirical study', British Journal of Religious Education 26(1), 33-44. http://dx.doi.org/10.1080/0141620032000149908

South Africa, 2003, 'National policy on religion and education', Government Gazette, no. 25459, Government Printer, Pretoria.

South Africa, Department of Basic Education, 2011, Nasionale Kurrikulumverklaring Verdere Onderwys en Opleidingsfase (Graad 10-12): Religiestudies, besigtig 03 Julie 2013, vanaf http://www.education.gov.za/LinkClick.aspx?fileticket=D9nES\%2B\%2BD

Spatt, I., Honigsfeld, A. \& Cohan, A., 2012, 'A self-study of culturally responsive pedagogy and reflective practice', Teacher Education and Practice 25(1), 52-67.

Steyn, H.J. \& Wolhuter, C.C., 2008, 'The education system and probable societal trends of the twenty-first century', in H.J. Steyn \& C.C. Wolhuter (eds.), Education Systems: Challenges of the 21st century, pp. 1-34, Keurkopie, Noordbrug.

Tianlong, Y., 2012, “"What is it that I Don\&apos;t know": Learning with white teachers in anti-racist education', Multicultural Education 19(4), 47-52.

UNESCO, 2006, UNESCO guidelines on intercultural education, UNESCO, Paris.

UNESCO, 2014, International standard classification of education - Fields of education and training, viewed 24 June 2014, from http://www.uis.unesco.org/Education/ Documents/isced-fields-of-education-training-2013.pdf

Van der Walt, J.L., Potgieter, F.J. \& Wolhuter, C.C., 2010, 'The road to religious tolerance in South Africa (and elsewhere): A possible "Martian perspective" religion" State \& Society 38(1), 29-52. http://dx.doi.org/10.1080/09637490903500507

Van der Walt, J.L. \& Wolhuter, C.C., 2005, 'Godsdiens as 'n moontlike faktor in onderwysstelsels en die beplanning daarvan', Koers 70(1), 1-26. http://dx.doi. org/10.4102/koers.v70i1.257

Verloop, N. \& Lowyck, J. (reds.), 2003, Onderwijskunde: Een kennisbasis voor professionals, Wolters-Noordhoff, Groningen.

Vermeer, P. \& Van der Ven, J.A., 2004, 'Looking at the relationship between religions: An empirical study among secondary school students', Journal of Empirical Theology 17(1), 36-59. http://dx.doi.org/10.1163/1570925041208899

Vroom, H.M., 2001, Religieus pluralisme en multikulturaliteit, NWO, Amsterdam.

Wolhuter, C.C., 2012, 'Godsdiens in onderwys in Suid-Afrika: Beligting vanuit internasionaal-vergelykende perspektiewe', Tydskrif vir Christelike Wetenskap 48(1 \& 2), 171-201.

Wolhuter, C.C., Potgieter, F.J. \& Steyn, H.J., 2011, "n Gevallestudie van die bydrae van sendingonderwys tot die ontwikkeling van Afrika - Omgekeerde spieëlbeeld van die stereotipiese uitbeelding in die literatuur', Tydskrif vir Christelike Wetenskap 47(1), 23-41.

Wright, A., 2004, Religion, education and post-modernity, Routledge Falmer, London. http://dx.doi.org/10.4324/9780203463499 